\title{
MANAGERS' DISCOURSE ABOUT INFORMATION AND KNOWLEDGE RELATED TO DIRECTLY OBSERVED TREATMENT OF TUBERCULOSIS
}

\author{
Rita de Cassia Cordeiro de Oliveira ${ }^{1}$, Karinne Dantas de Oliveira Adário², Lenilde Duarte de Sá3, Arieli \\ Rodrigues Nóbrega Videres ${ }^{4}$, Sérgio Augusto Freire de Souza ${ }^{5}$, Patrícia Geórgia Oliveira Diniz Pinheiro ${ }^{6}$
}

${ }^{1}$ Ph.D. in Nursing. Nurse, Fundação Nacional de Saúde. João Pessoa, Paraíba, Brazil. E-mail: ritaoliver2002@yahoo.com.br

${ }^{2}$ Master's student, Programa de Pós-Graduação em Enfermagem, Universidade Federal da Paraíba (UFPB). Technical Advisor, Health Work Management Board, Municipal Health Secretary. João Pessoa, Paraíba, Brazil. E-mail: karinnedantas@gmail.com

${ }^{3}$ Ph.D. in Nursing. Professor, Programa de Pós-Graduação em Enfermagem, UFPB. João Pessoa, Paraíba, Brazil. E-mail: sa.lenilde@ gmail.com

${ }^{4}$ Doctoral student, Programa de Pós-Graduação em Enfermagem, UFPB. Professor, Universidade Federal de Campina Grande. Cajazeiras, Paraíba, Brazil. E-mail: arieli.nobrega@hotmail.com

${ }^{5}$ Ph.D. in Linguistics. Professor, Departamento de Línguas e Literaturas Estrangeiras, Programa de Pós-Graduação em Letras, Universidade Federal do Amazonas. Manaus, Amazonas, Brazil. E-mail: sergiofreire@ufam.edu.br

${ }^{6}$ Doctoral student, Programa de Pós-Graduação em Enfermagem, UFPB. Professor, Faculdade de Ciências Medicas. Campina Grande, Paraíba, Brazil. E-mail: pgdinizpinheiro@hotmail.com

\begin{abstract}
Qualitative study that aimed to analyze the discourse of 15 district managers about knowledge and information related to the transfer of the Directly Observed Treatment of Tuberculosis policy in the city of João Pessoa, Paraíba, Brazil. The empiric material, collected in May and June 2013 through interviews, was analyzed according to Michel Pêcheux's Discourse Analysis. Despite contradictions, misunderstandings and silences observed in some discourse about this policy, the interviewees value the matricial support and the shared discussions involving the professionals, the management and the users, with emphasis on the rearrangement of the service in operating the Directly Observed Treatment of Tuberculosis. The need for investments in professional qualification is clear, with a view to refining the work process through the reorientation of practices from the perspective of continuing education, which represents a strong device for the exchange of knowledge and innovative proposals with a view to effective tuberculosis control.
\end{abstract}

DESCRIPTORS: Primary health care. Knowledge. Public policies. Tuberculosis. Health manager.

\section{DISCURSOS DE GESTORES SOBRE INFORMAÇÃO E CONHECIMENTO RELACIONADO AO TRATAMENTO DIRETAMENTE OBSERVADO DA TUBERCULOSE}

\begin{abstract}
RESUMO: Estudo qualitativo que objetivou analisar os discursos de 15 gestores distritais sobre o conhecimento e a informação relacionada à transferência de política do tratamento diretamente observado da tuberculose no município de João Pessoa, Paraíba. O material empírico coletado nos meses de maio e junho de 2013, da técnica de entrevista, foi analisado conforme o aporte teórico-analítico de análise de discurso na linha francesa pecheutiana. Apesar de contradições, equívocos e silêncios observados em alguns discursos sobre essa política, percebeuse que os enunciadores valorizam o matriciamento e as discussões compartilhadas envolvendo os profissionais, a gestão e o usuário, com ênfase na reorganização do serviço para operacionalização do tratamento diretamente observado. Assinala-se a necessidade de investimento na qualificação profissional, buscando aprimorar o processo de trabalho a partir da reorientação de práticas na perspectiva da Educação Permanente, que representa um forte dispositivo para troca de saberes e propostas inovadoras para o efetivo controle da tuberculose.

DESCRITORES: Atenção primária à saúde. Conhecimento. Políticas públicas. Tuberculose. Gestor de saúde.
\end{abstract}




\title{
DISCURSOS DE GESTORES SOBRE INFORMACIÓN Y CONOCIMIENTO RELACIONADO AL TRATAMIENTO DIRECTAMENTE OBSERVADO DE LA TUBERCULOSIS
}

\begin{abstract}
RESUMEN: Estudio cualitativo que objetivó analizar discursos de 15 gestores distritales sobre conocimiento e información relacionada a la transferencia de política del tratamiento directamente observado de tuberculosis en el municipio de João Pessoa, Paraíba, Brasil. El material empírico colectado los meses de mayo y junio de 2013 a través de técnica de entrevista fue analizado conforme aporte teórico-analítico de análisis de discurso de línea francesa pecheutiana. A pesar de contradicciones, equívocos y silenciamientos observados en algunos discursos sobre esa política, se percibió que enunciadores valorizan lo matricial y las discusiones compartidas envolviendo profesionales, gestión y usuario, con énfasis en reorganización del servicio para operatividad del tratamiento directamente observado. Se identifica la necesidad de inversión en calificación profesional buscando mejorar el proceso de trabajo a partir de reorientación de prácticas en la perspectiva de la educación permanente, que representa fuerte dispositivo para intercambio de saberes y propuestas innovadoras para el efectivo control de la tuberculosis.
\end{abstract}

DESCRIPTORES: Atención primaria de salud. Conocimiento. Políticas públicas. Tuberculosis. Gestor de salud.

\section{INTRODUCTION}

Tuberculosis is an infectious disease that affects all age groups and remains one of the main public health problems in the global context. It mainly strikes male economically active individuals between 15 and 54 years of age. The prevalence of registered cases is higher in highly populated areas, linked to important social, economic and health factors. Each year, about six million new cases of tuberculosis are notified around the world, causing more than a million deaths. Brazil currently ranks $16^{\text {th }}$ among the 22 countries with the greatest disease burden, being responsible for $80 \%$ of cases globally. ${ }^{1}$

The directly observed treatment (DOT) is one of the pillars of the Directly Observed Treatmentshort Course (DOTS) strategy, which the Ministry of Health launched in Brazil in 1996 to improve some indicators related to tuberculosis. It consists in the observation of medication intake, preferably every day, aiming for the strengthening of the patient's treatment compliance and the prevention of drugresistant strains of the disease. ${ }^{2-3}$

Studies undertaken ${ }^{4-5}$ in Brazil found Primary Health Care (PHC) services' low adherence to the incorporation of DOT and evidenced that the state and municipal authorities do not respond appropriately to the demographic realities related to the planning and funding of programs to minimize the so-called hidden costs of compliance with tuberculosis services.

In view of the reality tuberculosis produces, the Ministry of Health, as from 2001, undertook strategies to control this disease, combining tools through the articulation between the Family Health Strategy (FHS) and the Community Health Agent Program (CHAP), considering that both could facilitate the integration of activities related to the families and community groups. Therefore, prevention and disease control actions were expanded to improve some epidemiological indicators, such as the cure rate and the rates of abandonment and death. $^{2}$

Policy transfer is considered a development and/or movement model intended to provide meaning to a set of processes, in which the knowledge about institutions, services and systems in a certain sector or governance level is used to assess a given policy or program, mainly considering information and innovative actions in different places and contexts. ${ }^{6-8}$

In combination, knowledge and information are key elements in the policy transfer process of DOT. Policy transfer is intended to understand a process or set of processes in which different types of knowledge related to the institutions, programs, policies or systems in one governance sector or level are used to develop policies in another governance sector or level, like in the decentralization of DOT to the PHC service. ${ }^{9-10}$

In João Pessoa-PB, Brazil, the policy transfer of DOT was done in 2007 to the PHC services. Formerly, the treatment was centralized at the Complexo Hospitalar de Doenças Infectocontagiosas Clementino Fraga, the referral unit (RU) in the state. ${ }^{11}$ This transfer process represents a significant advance, despite imposing different challenges, such as the articulation of actions among the different technical-administrative-management levels of the health system.

For the implementation of DOT in the cities, effective negotiation is needed among the members of the management teams, namely among the coordinators of the Tuberculosis Control Program (TCP) and the managers of the Health Districts (HD), in the administrative and technical spheres. In that process, actions related to the policy transfer of DOT are undertaken that lead to the transfer of knowledge and information among the stakeholders in 
the implementation of the treatment, in view of the particularities and characteristics of each location.

As the analysis in this articles was focused on managers' discourse from the perspective of information and knowledge on the policy transfer of DOT for tuberculosis control in the city of João Pessoa-PB, the following question is raised: what does these managers' discourse express about the knowledge and information related to the policy transfer of DOT of tuberculosis in João Pessoa-PB? This problem emerged in view of the need to investigate the organizational and management aspects, which can act as obstacles to the effective incorporation and sustainability of the health services' disease treatment and control actions.

The importance of this kind of studies is due to the urgent need to recognize and socialize information and knowledge deriving from the DOT policy to the entire tuberculosis care network. Thus, the goal in this study was to analyze the discourse of district managers about the knowledge and information related to the policy transfer of DOT of tuberculosis in João Pessoa-PB.

\section{METHODS}

A descriptive and qualitative study with a discursive approach was undertaken in the city of João Pessoa-PB, which the Ministry of Health considers a priority city in tuberculosis control actions.

In João Pessoa-PB, the PHC network is distributed in regions, with five HD that administer 180 health teams, distributed in 125 Family Health Units (FHUs), totaling $88.3 \%$ of the population coverage. Each district service has its own administration, board, professional team, including the Matricial Supporters (MS), corresponding to the Family Health Support Group, and the Technical Supports, corresponding to the Workgroups (WG), including the WG on tuberculosis and Hansen's disease, considered a link between the FHUs and the Municipal Health Department.

Fifteen district managers participated in the study, who are considered enunciators, including five general directors, five technical directors and five technicians responsible for the TCP, selected because they are active in the management and coordination of tuberculosis control actions in the five HDs.

The data were collected in May and June 2013 through the directive and guided interview technique, which was divided in two parts. The first refers to the technical form, including the variables sex, birth date, function, length of experience in current function and instruction level. In the second part, the enunciators were invited to discuss the reasons and process of the policy transfer of DOT; their experience in the discussion of this problem with the PHC and TCP coordinators in the municipal or state sphere; the innovations in the disease control actions resulting from this process; the strategies the State or Municipal Health Department used at that moment; the aspects in favor of and against the policy transfer of DOT; as well as the actions the management used in patient care as part of DOT for tuberculosis control.

The data were collected individually with the help of an MP4 audio device inside the HDs, at places the enunciators had chosen, after proper clarifications about the ethical aspects, including the reading, delivery and signing of the Informed Consent Form. To preserve the anonymity, the managers were identified throughout the text using the letters DM (District Manager), followed by Arabic numerals representing the order of the interviews (DM1 till DM15).

The empirical data were analyzed using the theoretical analytic device of the French author Michel Pêcheux's discourse analysis (DA), introduced in the 1960's through his work Analyse automatique $d u$ discours. In DA, the intention is to apprehend the production processes of meanings in the relation among the language, ideology and subject, understanding how the language produces meanings through and for subjects, considering that there is no discourse without a subject and no subject without ideology. ${ }^{12}$

In DA, the data analysis plan starts with the circumscription of the analysis concept. This phase involves choice, interpretation and (discursive) analysis of the corpus through three heuristic questions: what is the analysis concept present in the text? How does the text construct the analysis concept? What discourse does the analysis concept belong to? The analysis concept is the object of the analysis, manifested through the definition of the analyst's interest in first defining the analysis concept before starting to set up the corpus (a priori analysis concept) or through its emergence during the analysis process (a posteriori analysis concept). ${ }^{13}$

In this study, the corpus consisted of the transcribed interviews with 15 DM enunciators. The following analysis concept was defined a priori: knowledge and information related to the policy transfer process of DOT in João Pessoa-PB. The corpus was repeatedly read in a constant movement 
of coming and going between theory and analysis, aiming to understanding the production processes of meaning.

The discursive analysis covered an excerpt from the empirical material, defined here as the transcribed interviews, for the discursive object, through the following phases: ${ }^{12} 1$ ) from the linguistic surface to the text (discourse); 2) from the discursive object to the discursive formation (DF), determines what can and should be said in an ideological formation; and 3) from the discursive process to the ideological formation.

In the first phase, the productive conditions of the discourse were observed, which fundamentally comprise the enunciators and the circumstances of the enunciation in the broader socio-historical and ideological context. At that moment, the intention was, using paraphrases, synonymy, polysemy, metaphors, circumstances of saying and not saying, ${ }^{12}$ to answer the second heuristic questions: How did the text construct the analysis concept?

As regards the productive conditions of the discourse, the enunciators were characterized as health professionals in management functions at the HD, with activities focused on the TCP, PHC and epidemiological surveillance, with an academic background in: Nursing (seven), Physiotherapy (two), Psychology (two), Physical Education (one), Social Services (one), Pharmacy (one) and Dentistry (one), holding lato sensu graduate degrees, having taken specialization courses in family health, public policies and/or health management (14).

In the next phase, contradictions were revealed and silences, errors, repetitions and hesitations in the enouncing district managers' discursive universe were identified. At this analysis level, ${ }^{12-13}$ it should be kept in mind that the discursive subject is inscribed in different DF because (s)he occupies different positions and, therefore, no linear relation exists.

In the final phase, the relations between the DFs and the effects of the ideology were observed. Through the text marks, considered as the entries in the discourse through the language, the texts were verified that were left out, signaling what these absent texts meant, what were the properties of the discourse, which DF they belong to and, finally, what is the ideological formation that supports it. ${ }^{12-}$ ${ }^{13}$ This was intended to answer the third heuristic question: What discourse does the constructed concept belong to?

Departing from these considerations, the statements on the knowledge and information related to the policy transfer process of DOT of tuberculosis in João Pessoa-PB were organized in the discursive block: information and knowledge on the DOT policy and interpreted.

The study received approval from the Research Ethics Committee of the Health Sciences Center at Universidade Federal da Paraíba (protocol 0301/2012/UFPB/CCS/CEP) in compliance with National Health Council Resolution 466/12 on research involving human beings.

\section{RESULTS AND DISCUSSION}

The policy transfer analysis is related to knowledge promotion in the political process and is intended to understand how knowledge and information is transferred among the institutions, policies or systems between one governance sector or level and another. Experts focusing on policy transfer are interested in understanding the predecision process and key authors working in "making policies", the management of these programs' transfer, the implementation and the causes of an error in these policies, as well as the aspects related to the political changes. ${ }^{6-7,14}$

\section{Discursive block: information and knowledge on the directly observed treatment policy}

The discursive analysis starts with DM1, highlighting the following text marks: [...] I didn't have difficulties no, because as I've already got the big tuberculosis book [...] I think that people who don't have that book face difficulties, who really does not have it, because you'll find people who won't have this book and won't have this monitoring (DM1).

The abovementioned document is the book to register and monitor the treatment of latent tuberculosis infections, which should be used as a tool for epidemiological surveillance actions at the health services, serving as a tool to calculate operational and epidemiological indicators. ${ }^{2}$

Based on the text marks highlighted, the discursive analysis of DM1's enunciation permits inferring that the manager has limited knowledge about the TCP and, more specifically, about the operation of DOT at the FHUs, as he considers that the ownership or availability of the book to monitor tuberculosis cases at the health service is sufficient, minimizing or eliminating the difficulties mentioned in DOT management. In that perspective, it is considered that DM1, as the manager responsible for the TCP actions in the HD, identifies with a DF 
that only values the material instruments as the main work tool for tuberculosis control.

This valuation was constructed based on an interdiscourse, marked by experiences of bureaucratic acts, the completion of forms and reports, procedures characterized as hard technology, used to produce health through dead work. ${ }^{15}$

Health production through live work corresponds to the expression that gives meaning to the work in action, at the exact moment of its productive activity. Dead work, then, refers to the machines and tools and receives this name because earlier work has been applied to them. When the work process is guided by live work, the worker is free to be creative, relate with the user, interact and take part in the production process of his own health. ${ }^{15}$

As regards the production of care and its technologies, three categories stand out in health: hard, light-hard and light technologies. The first refers to the machines and instruments used to produce the health actions. The second refers to the technical knowledge associated with the particular way in which the worker applies the technique and takes care of the user. The light technologies correspond to the relations, a manner or attitude characteristic of the professional, which is guided by a certain degree of intentionality linked to the field caregiver, his/ her way of being, his/her subjectivity. ${ }^{15}$

Another text mark was highlighted in the managers' enunciations about the PT process of DOT: [...] I think the active search. It's mainly what they have done (DM5). Considering that the active search is an activity to identify people who have been coughing for three weeks or more in an early stage, with a view to the discovery of bacilliferous cases and the delayed diagnosis of tuberculosis, ${ }^{2}$ and that, at the time of the interview, the care for confirmed patients was focused on, two hypothesis are highlighted concerning DM5's discourse: either the enunciator is not familiar with the actual TCP policy or, despite understanding the meaning of the active search, he did not pay attention to the scenario, to the actions the management performed in care delivery to DOT patients.

A study developed in 2010 involving matricial support managers from integrated services in the city of João Pessoa-PB confirms the present findings. In the analysis of these managers' discourse, the research identifies that they mixed up the active search for new cases with therapeutic monitoring or cases referring to treatment abandonment. ${ }^{16}$ Concerning the idea that the discourse is the effect of meanings between speakers, in DM5's discourse, effects with contradictory meanings are observed about the guidelines the Ministry of Health has established for tuberculosis control. That justifies the presence of the meaningless, the mistake, the meaning "other" ${ }^{12}$

Concerning the manager's experience with the policy transfer process in the city for the decentralization of DOT to the FHUs, the following text mark is highlighted: [...] all I do is to receive, how shall I say it?, the worksheets here at the district. So I don't participate. [...] She [Tuberculosis Program Coordinator in the district] only brings me information, the things I need to do, to complete (DM9).

Several times during the interview, the enunciator hides his responsibility, taking the stance of the passive manager, by indicating that his work is strictly bureaucratic. This fact distances him from an effective and high-quality work process he should know, achieve and take part in as a protagonist of that HD's management team.

In DM8's discourse, the text marks highlighted were: [...] yes... I've been here for five months, right? [...] But, before that, I was a supporter; I don't know if that contact took place there... [...] for them to go there and be able to overcome any difficulty [...] any support from other entities.

At the start of this discourse, it is shown that, at the same time as he justifies his recent admission to the manager job, the enunciator also informs that he has been a matricial supporter in the past, a fact that makes him present broader knowledge on the theme, as he has received relevant information on the DOT policy as a matricial supporter. Nevertheless, a void, doubtful and superficial discourse is noticed, announced at different times through nonspecific expressions like "some", clearly demonstrating the undefined nature of what they referred to, even when they were asked to further clarify what was said at that moment.

A similar position was revealed in DM4's discourse: [...] we are always trying to strengthen that theme [...] the adaptations that is us strengthening. The word "strengthen" was used several times in his discourse, encouraging the following reflection: based on what meaning was the discourse truly constructed?

The word "strengthen" means to make effective, to make active. In view of how frequently the municipal managers use it in their discourse, the following question should be raised here: when the manager emphasizes the term "strengthen", does he do that conscious of the meaning of the word or is it a mere repetition of something he has heard earlier? One could say that DM4 was subjected, being ideologically challenged by this idea, as his 
discourse contains no clues or traces of how DOT actions could be strengthened.

About the subjecting, ideologies act to constitute subjects and their forms of subjectivity, appointing that these individuals were always challenged by the ideology, leading them to the condition of "permanent already-subjects". In this case, the subject is both the subject of the action, of the practices, and a subject subjected to the Subject (with a capital S) that constantly challenges him, without being aware of this recognition/ignorance process of the subject with regard to the challenge. ${ }^{17}$

Based on the text marks identified in the discourse by DM1, DM5, DM9, DM8 and DM4, it can be inferred that these managers present a certain discourse that is unfamiliar with the policy transfer process and/ or the DOT policy, contributing to weaknesses in the conduction and organization of tuberculosis control actions in the city. As subjects-managers, they were expected to present a higher level of knowledge on the theme, as DOT was implemented in the city more than seven years earlier and some of them had already worked in $\mathrm{PHC}$ at other times.

Despite this frailty, the discourse reveals that other enunciators identified activities for the health professionals, which are capable of strengthening and/or enhancing the knowledge on the DOT policy. This policy is visible in the text marks: [...] qualifications, workshops (DM12): [...] lectures, meetings (DM11). Nevertheless, the meaning they attributed to the dissemination of this knowledge merely corresponds to the transmission, as highlighted in the marks: [...] we are responsible for transmitting the knowledge (DM5): [...] they always organize transfer workshops (DM13).

The ideological effect of these transfers appears as traditional discourse, based on mechanic action and vertical management, departing from the state to the city, from the managers to the health professionals, who are mere information receivers without background knowledge.

Also observing text marks regarding knowledge and information about DOT, the following is highlighted: [...] there is indeed a whole transfer of knowledge on the disease, on the physiopathology of this disease, also to reach treatments, treatment forms, drugs, medicines that are used, until getting to the importance of DOT. But there is a transfer from the city to the district and from the district to the family health team. This qualification does exist (DM3).

In addition, once again, there are opposite effects attributed to the information and knowledge on DOT. In other words, the discursive memory of enunciator GM3 is focused on the curative health care model, without evoking information about tuberculosis from the social and political viewpoint.

The meaning the manager attributed to the knowledge on DOT, referred as done in the form of a "transfer", discussed during team meetings, workgroup meetings, in short, the movements among the state, city and district levels do not permit strengthening processes whose developments would result in innovation. In policy transfer, the innovation is characterized as interactive learning, involving intense articulations among different agents, demanding new organizational formats in networks. ${ }^{9,18}$

Also, in DM3's discourse, silencing is perceived about the recognition of the social determinants of tuberculosis, devoid of sociopolitical attributes, such as an unfavorable socioeconomic position, comorbidity of tuberculosis and aids, alcoholism, chemical addiction, smoking, bad nutrition and access barriers to the health service. These determinants expose the complexity of the problem and the need to establish new strategies to cope with tuberculosis..$^{5,11}$

For the policy transfer of DOT, the information represents the moment when the service and the professionals who will execute this policy will use support relevant to what is being transferred. The knowledge, in turn, is related to the moment the professionals will start to eliminate and understand the policy that was received/transferred to their place of work. ${ }^{6-7}$

Although some managers emphasize the meanings as the mere transfer of knowledge, others, in turn, value the matricial support, the shared discussion about the DOT policy, involving the professionals, the management, the user and the Local Health Council, as evidenced in the text marks: [...] the professionals should be engaged in this discussion, how they think the DOT should be, and then see if we, caught a bit of the management proposal from them and even include the users, why not use the space of a meeting with the local health council and discuss that with the users? (DM15). [...] when we discover the need for matricial support in that theme, we schedule the theme, and that theme area will provide matricial support in the team. Not only in the team, but in the health district. Or if I identify any weakness, I can also turn to the health district, or... to the department, and build that bridge over there at the department too (DM12).

The DMs provide the matricial support. This refers to the support professionals from different 
areas of expertise provide to a team with a view to expanding the activity area and qualify their actions. Based on the proposal of the Brazilian National Continuing Education Policy in Health (PNEPS), the matricial support is a new production mode of health, in which two or more teams, in a shared construction process, create a pedagogical-therapeutic intervention proposal. ${ }^{19}$

The PNEPS departs from significant learning, which promotes and produces meanings and proposes that the transformation of the practices should be based on critical reflection about the actual practices of professionals active in the service network. The resignification of this work process calls for reflections on the professionals' work, the managers and TCP coordinators' articulation with the other PHC services, with a view to changes in their practice and the qualification of all stakeholders for the strengthening of the DOT policy in the city. ${ }^{19}$

The original logic of this matricial support was mobilized in DM2's discourse. That can be expressed when he evokes the meaning of matricial support through the following text mark: [...] we are even trying to change these training strategies of these professionals, trying to do it on the spot really, trying to discuss cases that are real to them (DM2).

DM2's discourse rests on an ideological filiation bordering on the valuation of collective knowledge, in view of the evocation of the professionals' reality and of the cases they accompany, as well as the presentation of a sense of dislocation of the information, as this empowers the team closer to the user. The importance of the health team professionals' importance for DOT is proven for different reasons, ranging from the establishment of bonding between professional - user, identification of social needs, qualified listening, to the management of adverse reactions. Among the points that need special attention, the resignification of these professionals' practices stands out. ${ }^{20}$

The workgroup consists of matricial supporters, experts who can add knowledge resources and contribute with interventions that enhance the problem solving ability of the health team primarily responsible for the case. The matricial supporter is considered a facilitator of the reformulation process of the health practices, intended to establish bonding, welcoming and accountability of the health teams to construct integral care through a therapeutic project, constructed during encounters, including the adoption of educative actions to promote the users' autonomy and participation in their treatment. ${ }^{21}$
When included in the tuberculosis and Hansen's disease workgroup, these matricial supporters do not only perform their primary functions, but articulate the actions involving these themes in their territory and qualify for shared knowledge construction. The creation of the workgroup for the matricial support is an innovative action in the city, as this support is an alternative used in the decentralization of the transfer policy, which is associated with the dilution of power. It is a transfer of responsibilities that permits the empowerment of the persons who are receiving that responsibility. ${ }^{21-22}$

The matricial support is a strategy to enhance the Family Health team's participation, increasing the possibility to put in practice the expanded clinic, as well as integration and dialogue among different specialties and professions. ${ }^{21}$ Thus, the city favors and permits further discussion and participation of the stakeholders, managers and professionals, leading to a dilution of knowledge and power by providing for a dislocation of something culturally centralized. ${ }^{19}$

Therefore, a slip takes form in the contradiction of meanings in the discourse, concerning the knowledge construction processes and the resignification of the work practices on the policy transfer of DOT. As observed, the enunciators DM15, DM2 and DM12 present the creation of the workgroup as an innovative action for the decentralization of the DOT policy, as the matricial support device has been employed in knowledge construction, from the perspective of innovating in tuberculosis control.9,19

On the other hand, the enunciators DM5, DM13 and DM3 assume a more traditional and knowledgeable discourse. That position ends up impeding the decentralization of power, as these managers unconsciously present their filiation with a transfer view, that is, with merely taking knowledge, without necessarily empowering the Family Health team. The meaning used here to empower the team is based on the sharing of information, ideas, experience exchange and strengthening of the processes to put the DOT policy in practice in $\mathrm{PHC} .^{22}$

Thus, it is inferred that the ability to produce, adapt, recontextualize and apply knowledge, in accordance with the needs and particularities of each organization and/or institution, is therefore a core issue for the policy transfer of DOT. That is important to transmit information amidst the negotiation processes during the transfer, as well as to reconstruct the knowledge through the professionals' learning processes at the institutions involved in the policy transfer of DOT and, what is more, the 
ability to turn this knowledge into innovative practices in the peripheries of the local health systems, where these professionals are truly experienced.

\section{FINAL CONSIDERATIONS}

The conduction and organization to operate the DOT at the FHUs represent one of the challenges for health management in the city studied. In the enunciators' discourse, contradictions, mistakes and silences were perceived concerning the knowledge and information about the policy transfer of DOT, of the guidelines of the Tuberculosis Control Program, resulting in slips in the meanings of accountability and co-participation based on the subject-position they occupy, in this case, as a part of the management team in the HDs.

In that sense, the management, through the workgroup and matricial supports, should start discussion and reflection processes, involving the coordinators of the Tuberculosis Control Program, of Primary Health Care, of the Epidemiological Surveillance program and the Family Health team, with a view to resignifying the practices and reorganizing the actions linked to the DOT policy in PHC.

Therefore, the management should invest in professional qualification, seeking to enhance and reorganize the work process, including practice changes from the perspective of the PNEPS, involving the quadrilateral: education, management, care and social control, adopting the problematization of the work process in the care networks of the Unified Health System. That represents a strong device, capable of approaching all stakeholders, optimizing the matricial support through discussions about tuberculosis based on the specific program offering space for knowledge exchange, for innovative proposals based on successful experiences, with a view to implementing actions planned for its effective control, mainly considering the users who take part in these care networks as the main actors.

\section{REFERENCES}

1. Ministério da Saúde (BR), Secretaria de Vigilância em Saúde. Boletim Epidemiológico. Brasília (DF): MS; 2014.

2. Ministério da Saúde (BR), Secretaria de Vigilância em Saúde, Departamento de Vigilância Epidemiológica. Tratamento Diretamente Observado (TDO) da Tuberculose na Atenção Básica: protocolo de enfermagem. Brasília: MS; 2011.

3. Peruhype RC, Bath-Hextall F, Galvão CM, Darlington $\mathrm{N}$, Palha PF. The effectiveness of educational interventions for health professionals in Direct Observed Therapy and the Directly Observed Therapy Short-Course strategy: a systematic review protocol. JBI Database of Systematic Reviews \& Implementation Reports [online]. 2014 [cited 2015 May 18]; 12(4):176. Available from: http://joannabriggslibrary.org/ index.php/jbisrir/article/view/996/1935

4. Souza MSPL, Aquino R, Pereira SM, Costa MCN, Barreto ML, Natividade M, et al. Fatores associados ao acesso geográfico aos serviços de saúde por pessoas com tuberculose em três capitais do Nordeste brasileiro. Cad Saúde Pública [online]. 2015 [cited 2015 Jun 18]; 31(1):111-20. Available from: http:/ / www.scielosp.org/ scielo.php?pid=S0102311X2015000100111\&script=sci_arttext\&tlng=en

5. Arakawa T, Arcêncio RA, Scatolin BE, Scatena LM, Ruffino Netto A, Villa TCS. Accessibility to tuberculosis treatment: assessment of health service performance. Rev Latino-am Enfermagem [online]. 2011[cited 2015 Jun 18]; 19(4):1994-2002. Available from: http:/ / www.scielo.br/scielo.php?script=sci_ arttext\&pid=S0104-11692011000400019\&lng=pt\&nr $\mathrm{m}=\mathrm{iso \& t} \operatorname{lng}=\mathrm{pt}$

6. Bissell K, Lee K, Freeman R. Analysing policy transfer: perspectives for operational research. Int J Tuberc Lung Dis [online]. 2011 Sep [cited 2015 Apr 25]; 15(9):1140-8. Available from: http:/ / www.ncbi.nlm. nih.gov/pubmed/21943837

7. Evans M. New directions in the study of policy transfer. Abingdon (UK): Routledge; 2010.

8. Sayım KZ. Policy transfer from advanced to lessadvanced institutional environments: Labour market orientations of US MNEs in Turkey. Human Relations [online]. 2011 [cited 2015 Jun 15]; 64(4):57397. Available from: http://hum.sagepub.com/ content $/ 64 / 4 / 573$

9. Carlfjord S, Lindberg M, Bendtsen P, Nilsen P, Andersson A. Key factors influencing adoption of an innovation in primary health care: a qualitative study based on implementation theory. BMC Family Practice [online]. 2010 [cited 2015 Apr 18]; 11(60):111. Available from: http://www.biomedcentral. com/1471-2296/11/60

10. Nedjat S, Majdzadeh R, Gholami J, NedjatS, Maleki K; Qorbani M, Shokoohi S, Ashoorkhani M. Knowledge transfer in Tehran University of Medical Sciences: an academic example of a developing country. Implement Science [online]. 2008 [cited 2015 Apr 18]; 3(39):1-8. Available from: http:/ / www.ncbi.nlm.nih. gov/pmc/articles/PMC2538542/

11. Sá LD, Andrade MN, Nogueira JA, Villa TCS, Figueiredo TMRM, Queiroga RPF, et al. Implantação da estratégia DOTS no controle da tuberculose na Paraíba: entre o compromisso político e o envolvimento das equipes do programa saúde da família (1999-2004). Ciênc Saúde Coletiva [online]. 2011 Sep [cited 2015 May 23]; 16(9):3917-24. Available from: http:// www.scielo.br/scielo.php?script=sci_ 
arttext\&pid=S1413-81232011001000028\&lng=en

12. Orlandi EP. Análise de discurso: princípios e procedimentos. 8a ed. Campinas (SP): Pontes; 2009.

13. Souza SAF. Análise de discurso: procedimentos metodológicos. Manaus (AM): Instituto Census; 2014.

14. James $\mathrm{O}$, Lodge $\mathrm{M}$. The limitations of 'policy transfer' and 'lesson drawing' for public policy research. Political Stud Rev [online] 2003 [cited 2015 Jun 18]; 1(2):179-93. Available from: http://onlinelibrary. wiley.com/doi/10.1111/1478-9299.t01-1-00003/full

15. Baêta NCA. Saúde: a cartografia do trabalho vivo. Cad Saúde Pública [online]. 2008 [cited 2015 Abr 18]; 24(8):1953-5. Available from: http://www. scielo.br/scielo.php?script=sci_arttext\&pid=S0102311X2008000800023

16. Pinheiro PGOD, Sá LD, Palha PF, Souza FBA, Nogueira JA, Villa TSC. Busca ativa de sintomáticos respiratórios e o diagnóstico tardio da tuberculose. Rev Rene [online]. 2012 [cited 2015 Abr 21]; 13(3):57281. Available from: http:/ / www.revistarene.ufc.br/ revista/index.php/revista/article/view/724

17. Chagas AT. O sujeito ideológico na perspectiva de Louis Althusser - o assujeitamento. Portal dos psicólogos [online] 2012 [cited 2015 Abr 18]. Available from: http://www.psicologia.pt/artigos/ver_artigo. php? codigo $=$ A0675

18. Jansen MWJ, Oers HAMV, Kok G, Vries NK. Public health: disconnections between policy, practice and research. Health Res Policy Systems [online]. 2010 [cited 2015 Abr 18]; 8(37):1-13. Available from: http:/ / www.health-policy-systems.com/content/8/1/37

19. Silva LAA, Ferraz F, Lino MM, Backes VMS, Schmidt SMS. Educação permanente em saúde e no trabalho de enfermagem: perspectiva de uma práxis transformadora. Rev Gaúcha Enferm [online]. 2010 Set [cited 2015 May 18]; 31(3):557-61. Available from: www.scielo.br/pdf/rgenf/v31n3/v31n3a21.pdf

20. Alves RS, Souza KMJ, Oliveira AAV, Palha PF, Nogueira JA, Sá LD. Tuberculosis treatment abandonment and comprehensive health care to patients in the family healthcare strategy. Texto Contexto Enferm [online]. 2012 Jul-Set [cited 2015 April 18]; 21(3):650-7. Available from: http://www.scielo.br/scielo.php?script=sci_ arttext\&pid=S0104-07072012000300021

21. Tenório CG, Campos GWS. Apoio Matricial e Atenção Primária em Saúde. Saude Soc [online]. 2011 [cited 2015 May 21]; 20(4):961-70. Available from: http://www.scielo.br/scielo.php?script=sci_ arttext\&pid=S0104-12902011000400013

22. Kleba ME, Wendausen A. Empoderamento: processo de fortalecimento dos sujeitos nos espaços de participação social e democratização política. Saúde Soc [online]. 2009 [cited 2015 May 18]; 18(4):733-43. Available from: http://www.scielo.br/scielo.php?script=sci_ arttext\&pid=S0104-12902009000400016 